\title{
Conservation of the Family Name Chromatiaceae Bavendamm 1924 with the Type Genus Chromatium Perty 1852 \\ Request for an Opinion
}

\author{
NORBERT PFENNIG and HANS G. TRÜPER
}

Institut für Mikrobiologie der GSF, 34 Göttingen, Germany

\begin{abstract}
The phototrophic red sulfur bacteria presently are placed in a family named Thiorhodaceae Molisch. However, this name is illegitimate because it was not based on the name of a genus. Of the genera placed in this family, five have familial names based on them. All of these names were published by Bavendamm in the same paper and, on the basis of page priority, Thiocapsaceae, with type genus Thiocapsa, is the correct name of this family. Nevertheless, the genus Chromatium Perty, which is the type genus of Chromatiaceae Bavendamm, is the best known and most studied genus of the red sulfur bacteria. Consequently, the Judicial Commission of the International Committee on Systematic Bacteriology is asked to conserve the familial name Chromatiaceae Bavendamm over the earlier subjective synonyms Thiocapsaceae Bavendamm, Lamprocystaceae Bavendamm, Thiopediaceae Bavendamm, and Amoebobacteriaceae Bavendamm. The family Chromatiaceae Bavendamm is emended to contain the genera Chromatium Perty, Thiosarcina Winogradsky, Thiocystis Winogradsky, Thiospirillum Winogradsky, Thiocapsa Winogradsky, Lamprocystis Schroeter, Amoebobacter Winogradsky, Thiodictyon Winogradsky, Thiopedia Winogradsky, and Ectothiorhodospira Pelsh.
\end{abstract}

Van Niel (11) was the first to obtain pure cultures of phototrophic red (purple) bacteria. Up to this time, all classifications of these organisms were based on observations of crude material collected from natural habitats and occasionally maintained as crude cultures (e.g., Winogradsky columns) in the laboratory. Thus the creation of higher taxa for these organisms was rather arbitrary and merely a matter of preference. Under these circumstances, van Niel (11) chose Thiorhodaceae Molisch for the name of the family of the red sulfur bacteria and Athiorhodaceae Molisch for the name of the family of red nonsulfur bacteria. However, these names are illegitimate because they are not based on the names of genera (Bacteriological Code, Rule 3). A request (9) to conserve these names was rejected by the Judicial Commission (2).

The name Rhodobacteriaceae Migula (4) is likewise an illegitimate family name for the red sulfur bacteria because it also was not based on the name of a genus. Migula (4) named a number of subfamilies, as follows: Thiocapsaceae (sic), Lamprocystaceae (sic), Thiopediaceae (sic), Amoebobacteriaceae (sic), and
Chromatiaceae (sic). Bavendamm (1) raised these subfamilies to the rank of families, added another family, the Rhodocapsaceae, and called the whole group Rhodo-Thiobacteria [Rote Schwefelbakterien (red sulfur bacteria)]. In a footnote (no. 4, page 115), however, he made the following important statement: "Die Abgrenzung der Familien, Gattungen und Arten ist bei der II Unterreihe teilweise noch unsicherer als bei der ersten." [Translation: The demarcation of the families, genera, and species within the second subgroup (i.e., red sulfur bacteria) is in part even more uncertain than within the first subgroup (i.e., the colorless sulfur bacteria).]

Bavendamm's classification and nomenclature have not been accepted by later taxonomists in this field. On the other hand, as mentioned previously, Molisch's name Thiorhodaceae is still generally in use for the family of the phototrophic red sulfur bacteria.

On the basis of extensive studies on pure cultures of nearly all the named species of this group (see 8), there appears to be no reason for maintaining more than one of the six families introduced by Bavendamm (1) for this group. 
Since the classical pure-culture studies by van Niel (11), Chromatium Perty 1852 has become the best known and physiologically and biochemically best studied genus of all of the genera of the phototrophic red sulfur bacteria. It contains nine recognized species, all of which are at present maintained in pure culture. All other type genera of the families named by Bavendamm (1) are not so well studied and contain fewer species. Bavendamm's arrangement of families is quite arbitrary and uncertain by his own statement.

Although it is not required, it is most helpful for a type genus to be the most typical and best known genus of a family. Applying this reasoning, Chromatiaceae Bavendamm 1924 should be the familial name for the phototrophic red sulfur bacteria replacing the earlier but illegitimate names Rhodobacteriaceae Migula 1900 and Thiorhodaceae Molisch 1906. In order to establish the legitimacy of the name Chromatiaceae, it is necessary to conserve it against the other family names created by Bavendamm (1) in the same publication just a few pages earlier. Consequently, it is requested that the Judicial Commission issue an Opinion conserving the name Chromatiaceae Bavendamm for the family of phototrophic red sulfur bacteria with Chromatium Perty as the type genus. The family Chromatiaceae includes the genera Chromatium Perty 1852, Thiosarcina Winogradsky 1888, Thiocystis Winogradsky 1888, Thiospirillum Winogradsky 1888 , Thiocapsa Winogradsky 1888, Lamprocystis Schroeter 1886, Amoebobacter Winogradsky 1888, Thiodictyon Winogradsky 1888, Thiopedia Winogradsky 1888, and Ectothiorhodospira Pelsh 1936.

\section{LITERATURE CITED}

1. Bavendamm, W. 1924. Die farblosen und roten Schwefelbakterien des Süß- und Salzwassers. Fischer, Jena.

2. Editorial Secretary for the Judicial Commission of the International Committee on Systematic Bacteriology. 1971. Minutes of Meeting of the Judicial Commission, Mexico City, Mexico. Int. J. Syst. Bacteriol. 21:101 (Minute 16).

3. International Code of Nomenclature of Bacteria. 1966. Int. J. Syst. Bacteriol. 16:459-490.

4. Migula, W. 1900. System der Bakterien, vol. 2. Fischer, Jena.

5. Molisch, H. 1907. Die Purpurbakterien nach neuen Untersuchungen. Fischer, Jena.

6. Pelsh, A. D. 1936. Hydrobiology of Karabugaz. Trud. Solyan. Lab. Akad. Nauk USSR, Moscow 5:49-80.

7. Perty, M. 1852. Zur Kenntnis kleinster Lebensformen. Jent and Reinert, Bern.

8. Pfennig, N. 1967. Photosynthetic bacteria. Annu. Rev. Microbiol. 21:285-324.

9. Pfennig, N., and H. G. Trüper. 1970. Conservation of the family names Thiorhodaceae Molisch 1907, 27 and Athiorhodaceae Molisch 1907, 28 and designation of Chromatium Perty 1852, 174 as the type genus of the Thiorhodaceae and of Rhodospirillum Molisch 1907, 24 as the type genus of the Athiorhodaceae. A recommendation to the Judicial Commission. Int. J. Syst. Bacteriol. 20:31-33.

10. Schroeter, J. 1886. In Cohn (1889), Kryptogamen-Flora von Schlesien 3:1-814.

11. van Niel, C. B. 1931. On the morphology and physiology of the purple and green sulphur bacteria. Arch. Mikrobiol. 3:1-112.

12. Winogradsky, S. 1888. Beiträge zur Morphologie und Physiologie der Bakterien. Heft 1. Zur Morphologie und Physiologie der Schwefelbakterien. Felix, Leipzig. 